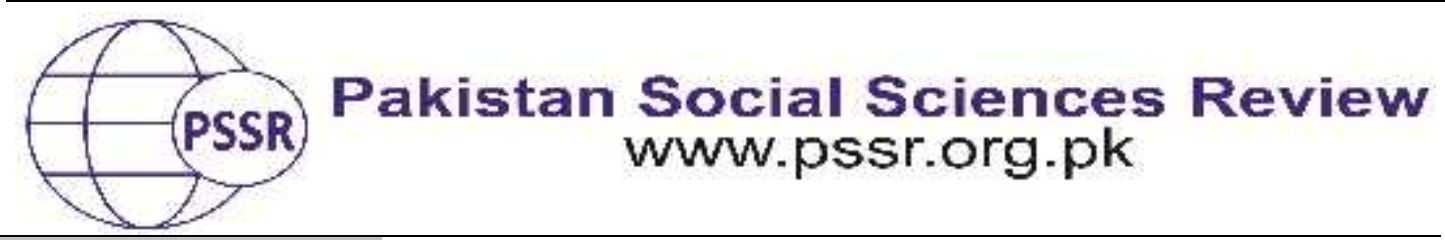

RESEARCH PAPER

\title{
Challenges and Opportunities of Technical and Vocational Education and Training in the Province of Sindh, Pakistan
}

Dr. Kamal Haider ${ }^{1}$ Prof. Dr. Muhammad Yousuf Sharjeel ${ }^{2}$ Dr. Shahid Iqbal ${ }^{3}$

1. Assistant Professor, Department of Education, Federal Urdu University of Arts, Science and Technology, Karachi, Sindh, Pakistan

2. Professor, Department of Teacher Education Federal Urdu University of Arts, Science and Technology, Karachi, Sindh, Pakistan

3. Assistant Professor, Department of Psychology, Federal Urdu University of Arts, Science and Technology, Karachi, Sindh, Pakistan

\section{PAPER INFO ABSTRACT}

Received: Vocational and educational training is an integral component March 23, 2021 for efficient and smart GDP of a country. With a higher rate of

Accepted:

July 01, 2021

Online:

July 20, 2021

Keywords:

Opportunities and

Challenges,

Technical

Education,

Vocational

Training and

Education

*Corresponding

Author

kamalhaider@fu

uast.edu.pk professionally trained manpower, a country can increase its exports and earn direct revenue. The paper attempted to employ survey research by virtue of social science research protocol as suggested by the experts in the field. The study comprised $n=50$ headmasters and $n=200$ teachers of technical and vocational schools of Sindh. To conduct the study further, pre-designed closed-ended instrument with Likert scale was used for quantitatively measuring the data impact. Data was collected through self-administered strategy and mailing as well as personal visits. Data were analyzed using SPSS software. Coding and communication were done adequately. Other measures of reliability and validity were also carried out accordingly. The study finds that vocational and educational training and skill-building practices must be compulsorily introduced in the schools and colleges across the province of Sindh.

\section{Introduction}

Vocational education is the education that makes a person well-versed in a certain technique or craft. The term was standardized in 1999 during the Second International Congress on Technical and Vocational Education held in Seoul (Technical and vocational training (TVET) policy in Rwanda, 2008, Ministry of Education, Rwanda). The Congress decided that the best, most comprehensive term to use is Technical and Vocational Education and Training (TVET). This is usually in support of some profession such as engineering, medicine, architecture, computer etc. Such educations were based on manual or practical activities, but with the advent of computer software, applications have also been included in this segment 
of education. Sometimes they are also called technical education. Vocational education mostly takes place at secondary level. However, in certain cases, postsecondary vocational education is also considered where the level of understanding needs a better education. Vocational education is provided by specialized institutes or by a local college having such facilities. Vocational education is also defined as training for any specific skills in agriculture, industry or trade. It is specifically designed for learners to gain the skills, knowledge and abilities related to a particular field so that they may be economically independent. If one is able to complete the vocational education, he/she may be regarded as a successful labor who is professionally skilled in the labor market.

Vocational education is also known as VET (Vocational Education and Training). Basically, it refers to the study whose aim is to prepare skilled individuals that either revolves around manual or practical activities. Traditionally speaking, it is not academic based and is only related to certain specific skills, trade, occupation or vocation. But because it is mainly based on vocation, it is called Vocational Education. Carnoy and Luschei (2008) studied lifelong learning in Peru's Asparagus industry. They found that private sector in Peru took the lead in providing opportunities for lifelong learning to its workers. They concluded that government sponsored initiatives can be improved and expanded to support the private sector initiatives.

Seyihoglu Ayşegül and Kaptan (2011) studied elementary students' opinions of learning objects. They found that students had positive opinions on learning objects. The students found the learning lessons enjoyable and entertaining. It was thought that use of learning objects would aid students to overcome problems they face during their studies and make their attitude positive. Tripney and Hombrados (2013) studied technical and vocational education and training (TVET) in low and middle-income countries. They examined 26 studies and evaluated 20 interventions from South American countries. Paid employment and monthly earnings were found to be small, but positive and significant. Heterogeneity was found to be significant. European Centre for the Development of Vocational Training reviewed the benefits of vocational education and training (VET). It was found that Europe launched a strategy for swift recovery and growth from economic crisis. Education and training including other forms of learning were found to be necessary for sustainable growth. VET was considered to play an important part for more knowledgeable societies.

Hawley and Paek (2005) analyzed the economic payoff for vocational technical education followed by employment in a related occupation in Thailand and Korea. They found that relatively few men and women got a job they are trained for. However, men in Korea and women in Thailand related field employment get higher monthly earnings. The authors feel that there is a need for national development plans to address the issue of initial training and employment relationship. Fraser (2014) studied the role of technical and vocational education and 
training and donor agencies in developing countries. He found that there is a need to reduce the skill gaps and unemployment. He felt the need of collaborative approach among all the stake holders i. e. government, industry, TVET providers and students/parents. Schmidtke and Chen (2012) quoted Yang (2016) as saying that 2005 was a changing year in China for its educational and vocational philosophy. In this year, the government advocated a strategic concept creating a learning society with a focus on lifelong learning. It was concluded in the article that because of the Chinese respect for traditions, structuralist-functionalist approach will prevail, borrowing from Western models will continue.

Glauser and Becker, (2016) studied regional opportunity structures on educational attainment in German speaking Switzerland. They found that regional opportunity structures have a direct effect on type of the education at secondary level. Pupils attend general education when more extensive regional opportunities are available. Pupils with restrictive opportunities opt for vocational education and training (VET). According to Anning (2016) China has vocational universities (VU). These are non-traditional, universities offering sub-baccalaureate programs. Abdelkarim (1997) recorded the experience and views of vocational trainees in Philippines. He introduced a triangle in this regard. The triangle consists of industrial training studies, cost of training and the trainees. The trainees found the program interesting and relevant to their jobs.

\section{Challenges and Opportunities in VET}

Vocational Education is beneficial not only for the individuals, but also for the nation. It increases the productive capacity as well as skilled labor of a country. It also differs from one country to another based on the wide-ranging social class and the different cultures prevailing in the respective societies. It is designed to prepare the individuals for jobs. There are many schools, colleges and institutes all over the country which train the students and provide them with hands-on experience. It can also be defined as job-oriented education. It is very helpful for those who want to set up a small business or establishment of their own and earn their livelihood. In some places, the institute enrolls students at a very young age. They are then trained in a field of their liking so as to acquire specialization according to the needs of the employer.

According to Caselli (1999), there are some technological inventions such as electrification and ICT that are more skill-based in nature, whereas the assembly line technology has more resemblance towards unskilled labour. There are many studies in the European countries that are in favour of US stance of having positive attitude with workforce education and the adoption of advanced technologies. The main idea that comes from observation in the studies is that the workers who are high-skilled are more helpful than the low-skilled workers in the process of selecting, installing, operating and mainstreaming of ICTs. But the comparisons of these studies with the cross-country studies show that it is not a good idea to generalize too much about 
the education system of Europe as there are stark differences between the general and vocational education of the other countries.

Pakistan's education and vocational training systems are administered by the federal and provincial authorities. The national commission for technical and vocational education training works on policy making, curriculum development, and standard development. The implementation on provincial level is kept in check and balance by the technical education and vocational training authorities of the provinces comprising Sindh technical education and vocational training authority, Punjab technical education and vocational training authority, Khyber Pakhtunkhwa technical education and vocational training authority and Baluchistan technical education and vocational training authority. These are the provincial legal authoritative bodies to promote and regulate and strengthen technical education and vocational training.

In technical and vocational education training, three-year diploma programs are offered. Vocational institutions also offer certification programs and apprenticeship. The major initiative of technical education and vocational training by Sindh government is the establishment of Benazir Bhutto Shaheed development program and establishment of technical education and vocational training authority to bring the system of technical education, labour department and social welfare under one umbrella so that the market can get a good message and the required standard can be maintained. The importance is given to the governance of the program so that the policy making can be implemented. The stakeholders and employers are involved in different programs so that relevance is increased. On institutional level, institute management committees are developed and local employers are made the chairman of these committees so that they can strengthen the training activity of that center.

In Pakistan, the present system of technical education and vocation training lacks the expertise. There is a complete mismatch between what is taught and what is required by the local market. The training in the system is not provided accordingly to the demand of the system. This is due to the fact that the role of the local industry or the employers who are the end users of the trained manpower has very limited say in policy making and delivery of technical education and vocational training. There is a deficiency of good trainers in the system. Technical education and vocational training are built on general education, the raw material i.e., the students to be utilized for this field lack knowledge and this produces poor quality work. The labor market information system is very weak. It is not familiar with the demands of its local industry and what is required in the future and further the planning is not relevant as there is no reliable data. This is another reason for the economy to suffer. Throughout the world, the data and requirements are looked upon for giving the appropriate training to the workers. 


\section{Literature Review}

\section{Importance of Vocational Training}

Usually, the educators that have relatively higher level of qualification are more likely to get better opportunities for employment. Vocational training plays a significant role in filling the gap between general education of young people and jobs in labor market. Training schemes are not appropriate enough to support the smooth flow of vocational training. However, there is an active evaluation process for policy programs related to labor market. Models that are associated with dual apprenticeship are more productive and valuable as compared to vocational schooling because it leads to comparatively lower rate of unemployment among young people. Moreover, transition from school life to practical life of work becomes smooth and subsequently problems that may be encountered during career of labor market are reduced. If policy schemes for the betterment of vocational training are introduced and implemented whole-heartedly, the condition of youth in labor market can be improved consequently (Rogers, 2012).

\section{Significance of Vocational Training}

Many students acquire the degree of graduate and postgraduate each year. Subsequently, they desire to get compatible jobs with handsome salary package according to their higher qualification. Sometimes, the long-term studies of the students prove to be aimless due to lack of proper guidance related to their field. Therefore, they often do not get white-collared jobs and remain unemployed. In addition, they find themselves unsuitable for several jobs. Lately, it has been recognized by various colleges that vocational training is the need of hour. So, they have adapted certain courses relevant to vocational education as well as vocational training. When students get involved in sessions of training, they get to know exact pathway to their career instead of living in the world of fantasy or hopelessness. It assists them to get employment in various occupations according to the specialized skills they have acquired as a result of vocational training. Moreover, it helps both in pecuniary as well as non-pecuniary aspects. It leads to comparatively more stable employment as well a more satisfaction for job with increased earnings.

Vocational training helps the young people to become a helping hand for their families who have invested heavy amount on studies and have consumed time to build career for their children. It assists the students to pick up modern methods of a particular field rather than just following the curriculum of general education.(Matlay, 2008) Moreover, it benefits them to establish technical skills at relatively lower age and even provide sustenance to set up small business at their own potentials and will. In this way, vocational training can also be termed as joboriented training because it provides the job security. Many of the industries also hold responsibility of conducting vocational training in order to take freshly graduate students and train them accordingly. Subsequently, they recruit such students as employers of the industry. They also provide small amount of incentives 
as well as salary to young people during the session of training. (Richardson \& Berg, 2002).

\section{Benefits of Vocational Training}

There are certain economic and social benefits of vocational training. As a consequence of vocational education and training, there is enhanced economic growth in addition to better outcomes of the labor market substantially (Pereira et al., 2016). Subsequently, firms perform effectively which in turn opens pathway for more opportunities of employment and productivity of the young productivity. Furthermore, dramatic increase in earnings and professional status of youth is observed. As far as social benefits of vocational training are concerned, there is a drastic reduction in rates of crime. It leads to social cohesion and better health of the state. Moreover, it results in intergenerational advantages and inclusion of the disadvantages groups of youth. It increases the individual motivation and life satisfaction of the employers (Colley et al., 2003).

Short-term perquisites of vocational training include innumerable chances for employment and elevated levels of earning sources and work satisfaction. There is increased possibility of getting more productivity from the well trained and skilled workforce. Over and above, there are least chances of drop out from vocational training as compared to general courses. In addition, the costs and time are saved which is required for the purpose of hiring the skilled workers from external means. It saves expenses for the sake of social benefits by lowering the chances of unemployment as a result of unsuccessful transition from the years of education to work life. Long-term perquisites of vocational training include mobility as well as flexibility of the young employers. It helps to gain learning that is life-long and helps to receive training regarding advanced technical skills across other jobs in later life. Moreover, it improves the image of employer in the labor market and in turn lessens the chances of turnover. Consequently, it is not required to retrain the new works that are recruited in a particular occupation. Furthermore, there is a dramatic enhancement of income tax from the relatively higher earnings and long term glooming effects on rate of productivity (Hoeckel, 2008).

Vocational training allows the students to seek knowledge at their pace according to abilities. This is because some of the students are interested in comprehending each concept deeply to analyze the subject thoroughly. On the other hand, general education deals with all the students at equal pace despite their variable styles of learning. Unluckily, most of the institutions fail to comprehend different learning methods adopted by the students. Therefore, their assessment criteria are mainly confined to examination results only. Vocational training provides the students with platform to acquire expertise in a particular subject.

In addition, vocational training makes the learners highly capable for corporation of world at relatively higher pace and affectivity. It boosts the confidence level and enables to gain entry in labor market easily. It polishes the skills 
whether they are related to foreign language or information technology and subsequently prepares for the jobs. It removes all marks of hesitance regarding initiation of particular occupation. It brings innovative and radical change in workforce of the entire country (Kay et al., 1992).

Vocational training has glooming effects on development of the communicational skills. It helps to increase exposure not only to content, but also to the people that are present along the same session of training. Hence, it reforms the social profile by increase in interaction with other people. Furthermore, it helps to break the monotonousness of study and develops ability of developing study habit that is not healthy (Smits, 2008).

\section{The Cost of Vocational Training}

In broad terms, vocational training is often interpreted as job-oriented learning in various centers such as formal technical and vocational schools and workplaces. However, certain constraints that are posed by limited budget of the government for education and training increases the demand of managing the costs of both aspects effectively. Therefore, the major requirement of the hour is to identify the economic feasibility of vocational training and estimate the total cost essential for smooth running of vocational training institutes. Moreover, it is necessary to highlight the effectiveness of cost for such training programs by analysis of their productive outputs.

General education as well as vocational training is considered as production systems that require handsome amount of money. The major objective of vocational training that is mainly sponsored by the government is to fulfill the requirements of manpower economy. Several trainees, equipment, physical facilities and instructor time in addition to instructor materials are some of the inputs needed for the progression of vocational training. Many resources are vital to manage the smooth availability of these inputs and this in turn requires constitution of costs. Beyond this fact, the positive effects on the student, trainee and wage earner of the training are considered as outputs of the vocational training. Trainees develop cognitive skills to work effectively in the workplace as a consequence.

The training organizations, schools, enterprises, instructional strategies, pedagogy and different management procedures encircle the technology that serves as requisite for the vocational training. Training can be done in two forms either onthe profession or off-the profession. Other sources for vocational training include courses that are mainly conducted by different production units and proprietary schools. Customers and suppliers also take benefit from vocational training to gain knowledge of equipment use. Training programs are becoming more useful for many policy makers day by day due to involvement of various modes of vocational training. They have been formally integrated into the national system by the public sector. Vocational training is proved to be fruitful when it results in more apropos outcomes and multiple benefits with provision of same types of inputs. Sometimes, 
the gross expenditure on proper functioning of training framework during the vocations is determined to evaluate the productivity and quality. Obviously, when even less cost makes vocational training to run adequately, it is more effective on internal as well as external basis.

Vocational education, in addition to vocational training, provides schoolbased/vocational training as well as experience of work place. The responsibility of dual education is usually divided between various sectors of the society. For instance, firms hold the responsibility of ensuring financial stability of work place that is occupied for the purpose of vocational training. Similarly, states give the platform for getting education in vocational schools. The course participants have the fixed-term contract in terms of employment during the session of vocational training. They usually perform their duty to level of reduced wage.

The purpose of duality is to integrate general skills in youth that are transferrable across various course participants within a specific employment. Vocational training provides means of high motivation as well as relatively higher output of career-oriented youth because it enables them to gain practical experience relevant to labor market work. The course of vocational training includes central examinations ad standardized curriculum that ensures high level of transferability of technical skills. The system is managed by collaboration of unions, educational institutions and several employers likewise.Usually, school-based vocational training is carried out purely at training institutions either during the course of compulsory school level or as formalization pathway during post-compulsory level also known as upper secondary level. Generally, funds for this purpose are paid by the state. A curriculum containing general skills as well as occupation-specific qualification is followed formally. Budgetary constraints often restrict certain youth to get training. However, vocational training demands less time and costs and therefore allows maximum young people to participate and gain technical potentials that subsequently helps them in practical work life. After completing the session of vocational training, young people are only required to acquire on-the-job training and gain entry in labor market easily.

On-the-job training opens pathway for absolute progression from school to work life. Moreover, it helps the young employers to get better package of salary in short period of time as compared to other training programs as part of first stage. Nonetheless, the process of acquirement is limited to learning during the job without getting any certificate. Therefore, such learning method is less valuable across other jobs. As a consequence of inadequacy of occupational skills, the employers become more vulnerable to risk of getting subordinate position in the labor market. (Biavaschi et al., 2012).

\section{Schools-based VET and Workplace Training}

Student fees in addition to charges for equipment are required for vocational training that is entirely school-based. However, for employers, there is financial 
support and paid time is off. The allocation of funds to education and training institutions is done by the members of the state. Furthermore, state is also responsible for providing vouchers, loans, scholarships and loans. On the contrary, workplace training allows entry of students having lower wages. However, a lot of investment and opportunity costs are required for the purpose of training the unskilled workers. Employers are needed to pay wages that are usually higher as compared to productivity. In most of the cases, several mistakes are expected from the trainees that are inexperienced and comparatively less skilled which in turn, wastes many resources in addition to precious time of the experienced, skilled and potential workers. State plays a significant role in subsiding to vocational training institutions and firms. (Macours et al., 2013).

\section{Significance of Online Vocational Courses}

Gaining vocational education by means of online courses help the person to learn whatever he desires and require without spending any expense on traveling and residing in unknown place. It is suitable for students as well as for adult learners as it removes risks that may limit the potentials of gaining knowledge. They become fearless of failure in public so they attain vocational education potentially and more effectively. It provides comfort as there is no need of following rules and regulation of particular traditional institutions. It leaves a great impact on resume and increases chances of getting better employment. It is entirely self-paced learning, more convenient, more flexible, cost effective, unrestricted and immediate. Online facility for vocational education helps the learners to customize their own learning experiences. They have complete control on their learning procedure. For instance, if they like a particular topic and get skilled, they go for its complete details rather than getting tedious tasks for undesirable subject and waste time. It allows them to work at any time at any place without any restriction as online vocational courses do not disturb the home life. However, online vocational education has certain limitations as well. It is impersonal and requires self-discipline as it is completely a solo act.(Holttum, 2013).

Despite its limitations, online vocational learning is progressing fast to meet the demands of learners to attain skills regarding a particular occupation of their interest and requirement. Several visionaries and researchers believe the online vocational courses have brought a radical and transformed change in school system for last 50 years when system of industrial aged was setup for one-size-fits. Rapid and dramatic increase in number of enrollments in online vocational courses clearly indicates the increasing trend of online vocational education (Metz, 2010)

\section{Material and Methods}

The study employed survey research. All head masters and teachers of technical schools of Sindh were the population. The sample size was $n=50$ headmasters and $n=200$ teachers of technical and vocational schools of Sindh. A predesigned closed-ended questionnaire with Likert scale was used for quantitative 
survey. Data was collected through self-administered process of survey including surface mail and personal visits where applicable. Data were analyzed using SPSS software. All the required protocol was followed per the study needs. Coding and communication were done adequately too. Other measures of reliability and validity were also carried out accordingly.

\section{Results and Discussion}

\section{Hypothesis 1}

There is a significant association between enrollments for TVET substantially in the province of Sindh and challenge faced by the parents in educating their children.

Table 1

Test of hypothesis 1

\begin{tabular}{cccc}
\hline \multicolumn{4}{c}{ Chi-Square Tests } \\
\hline \\
Value & Df & Asymp. Sig. (2-sided) \\
\hline Pearson Chi-Square & $243.671^{\mathrm{a}}$ & 9 & .000 \\
\hline Likelihood Ratio & 182.007 & 9 & .000 \\
\hline Linear-by-Linear Association & 123.641 & 1 & .000 \\
\hline N of Valid Cases & 203 & & \\
\hline
\end{tabular}

a. 8 cells $(50.0 \%)$ have expected count less than 5 . The minimum expected count is .38.

The hypothesis is proved to be significant with $n=203$ participants. Enrollment for TVET has increased substantially in the province of Sindh and challenge faced by the parents in educating their children. The test is highly significant as the Pearson chi-square value reads 0.000 on a two-tailed probability distribution. We conclude that there is significant association between enrollments for TVET in the province of Sindh and challenge faced by the parents in educating their children. The Pearson chi-square value reads 243.67 against $p$-value of 0.000 .

\section{Hypothesis 2}

There is a significant association between measures to improve TVET in the province of Sindh and the challenges faced by the parents in educating their children.

Table 2

Test of hypothesis 2

\begin{tabular}{lccc}
\hline \multicolumn{4}{c}{ Chi-Square Tests } \\
\hline & Value & Df & Asymp. Sig. (2-sided) \\
\hline Pearson Chi-Square & $189.737^{a}$ & 9 & .000 \\
\hline Likelihood Ratio & 147.663 & 9 & .000 \\
\hline
\end{tabular}




\begin{tabular}{lcc}
\hline Linear-by-Linear Association & 100.726 & 1 \\
\hline N of Valid Cases & 203 & .000 \\
\hline a. 9 cells $(56.3 \%)$ have expected count less than 5 . The minimum expected count is .30. \\
\hline
\end{tabular}

The hypothesis is proved to be significant with $n=203$ participants. The test is highly significant as the Pearson chi-square value reads 0.000 on a two-tailed probability distribution. The Pearson chi-square value reads 189.73 against p-value of 0.000 . We conclude that there is significant association between measures to improve TVET in the province of Sindh and the challenges faced by the parents in educating their children.

\section{Hypothesis 3}

There is a significant association between vocationally-trained personnel and substantial increase in household income.

Table 3

Test of hypothesis 3

\begin{tabular}{lccc}
\hline & \multicolumn{4}{c}{ Chi-Square Tests } & \\
\hline & Value & Df & Asymp. Sig. (2-sided) \\
\hline Pearson Chi-Square & $203.313^{\mathrm{a}}$ & 6 & .000 \\
\hline Likelihood Ratio & 96.744 & 6 & .000 \\
\hline Linear-by-Linear Association & 71.607 & 1 & .000 \\
\hline N of Valid Cases & 203 & & \\
\hline
\end{tabular}

a. 6 cells $(50.0 \%)$ have expected count less than 5 . The minimum expected count is 12 .

The hypothesis is proved to be significant with $n=203$ participants. The test is highly significant as the Pearson chi-square value reads 0.000 on a two-tailed probability distribution. The Pearson chi-square value reads 203.313 against p-value of 0.000 . We conclude that there is significant association between vocationallytrained personnel and substantial increase in household income.

\section{Findings}

Most of the students opt for vocational training after completing graduation to get trained with technical skills of particular field according to their desire and requirement. In Pakistan, the significance of vocational training has been recognized to large extent. Therefore, Labor and Manpower, Agriculture, Ministries of Education and several industries work in collaboration to promote technical training and ensure maximum productive outcomes. They device various strategies and programs to provide the students with maximum technical skills that could help them in getting better jobs later in life.

In previous years, vocational training was mainly confined to low-level workers who required skills regarding working of particular machinery and performing of manual tasks. In addition, even universities and certain colleges also 
used prioritize theory matters and certification over training. There was almost negligible allocation of funds and budget for vocational training by the public sector. But, in present days, the scenario and perception of education is entirely different. All educational institutes give emphasis on dire need of providing platform to students whereby students can acquire skills with the help of several training instructors, efficient learned and inclusive learning environment. Many organizations that work for the purpose of tourism, information and technology, fashion, management and retail consider vocational education and training as the foremost priority. Most of the sectors of Pakistan recruit employers after training them with inquisitive number of certain skills and potentials. With access to various modes of information technology, it is easier for the vocational training to become accessible and convenient for trainees as well as for the training organizations. This is because it becomes easy for the instructors to convey the instructions to students and clarify their concepts by means of technology (Campbell, 1987).

\section{Recommendations}

The study recommends that development of skills by means of online vocational courses must be increased as the measure to of getting employed in jobs that have relatively higher rate of earning. It is recommended to consider people who are mainly responsible for recruiting the employers and are concerned about getting skilled and experienced individuals. Skill development by means of internet facility helps the young people to become a helping hand for their families who have invested heavy amount on studies and have consumed time to build career for their children. It is also a recommendation to assists the students to pick up modern methods of a particular field by web-based training rather than going to institutions and seeking vocational education (Liu and Clayton, 2016).

The study recommends to get people employed in various occupations according to the specialized skills they have acquired as a result of online vocational training. The study recommends this because it helps both in pecuniary as well as non-pecuniary aspects. It leads to comparatively more stable employment as well as more satisfaction for job with increased earnings. Differences regarding length of transition period greatly influence the intensity of risks prevalent in labor market so it is recommended that these risk factors be included as unemployment spells, low pay and temporary employment. In most of the countries, low qualification level commonly leads to high exclusion risks and least availability of jobs. On the contrary, skilled and highly qualified youth tend to have relatively more opportunities and platforms for getting jobs with handsome salary and adequate facilities. These facts help us to understand that recommendations given above must be pondered for a long(Hanushek et al., 2017).

\section{Conclusion}

University graduates do not get matching jobs according to their high qualification due to lack of skill development related to their desired profession. 
Subsequently, they desire to get compatible jobs with handsome salary package according to their higher qualification. Sometimes, their long-term studies prove to be aimless due to lack of proper guidance related to their field. Therefore, they often do not get white-collar jobs and remain unemployed. In addition, they find themselves unsuitable for several jobs. Online vocational education has a great impact on development of skills that could help the individuals to meet the requirements of competent markets. (Van Gelderen et al., 2005).

Long-term benefits of online vocational education include mobility as well as flexibility of the young employers. It helps to gain learning that is life-long and helps to receive training regarding advanced technical skills across other jobs in later life by sitting at home. Moreover, it improves the image of employer in the labor market and in turn lessens the chances of turnover. Consequently, it is not required to retrain the new works that are recruited in a particular occupation. (Hoeckel, 2008) Virtual classrooms for vocational education allow the students to seek knowledge at their pace according to abilities. This is because some of the students are interested in comprehending each concept deeply to analyze the subject thoroughly. On the other hand, traditional classroom deals with all the students at equal pace despite of their variable styles of learning.

The study concludes that the respondents are convinced that the scope of TVET will be increased in the coming years. They think that TVET enrollment will be increased substantially in the province of Sindh. It is also concluded that the Sindh government has taken several measures to improve TVET and challenge faced by the teachers in educating their students. Opportunities in TVET have been adequately explored and challenges faced by the parents in educating their children are being taking care of. TVET workers contributes substantially to the household income in the province. TVET learners are more motivated in TVET. The numbers of TVET institutes are enough in Sindh to meet the demand. The study concludes further that teachers have enough technical skills to impart to the students. The employment potential of TVET is sufficient to attract the learners. The income potential of TVET workers is sufficient to attract the learners

\section{References}

Abdelkarim. A (1997). Technical and Vocational Education and Training in the Philippines: Experience and Views of Trainees. International Journal of Manpower, Vol. 18 Issue: 8, Pp.675 - 701.

Anning. D (2016). China's Vocational Universities. Eric Digest.

Biavaschi, C. et al (2012). Youth Unemployment and Vocational Training.Vocational Education Journal. Vol 6. Issue 4.

Campbell, C. P. (1987). Instructional Systems Development: A Methodology for Vocational-Technical Training.Journal of European Industrial Training, 11, 3-42. 
Carnoy. M, Lushhei,T. F. (2008) Skill Acquisition in "High Tech" Export Agriculture: A Case Study of Lifelong Learning in Peru's Asparagus Industry,Journal of Education and Work, v21 n1 p1-23 Feb 2008.

Caselli.F. (1999). Technological Revolutions.American Economic Review, March 1999, Vol. 89, No 1, Pp. 80-1.

Colley, H., James, D, Diment, K. \& Tedder, M. (2003). Learning as Becoming in Vocational Education and Training: Class, Gender and the Role of Vocational Habitus. Journal Of Vocational Education And Training, 55, 471-498.

Fraser. S (2014) The Role for Technical and Vocational Education and Training and Donor Agencies in Developing Economies. Global Policy Volume 5. Issue 4. November 2014.

Glauser. D and Becker. R (2016). Vet or General Education? Effects of Regional Opportunity Structures on Educational Attainment in German-Speaking Learners.American Economic Review. October 2016.

Hanushek, E. A., Schwerdt, G., Woessmann, L. \& Zhang, L. (2017). General Education, Vocational Education and Labor-Market Outcomes Over the Lifecycle. Journal Of Human Resources, 52, 48-87.

Hawley. J. D, Jeeyon. P (2005)Developing Human Resources for the Technical Workforce: A Comparative Study of Korea and Thailand. International Journal for Training and Development.

Hoeckel, K. (2008). Costs and Benefits in Vocational Education and Training. Paris: Organisation for Economic Cooperation and Development, Vol 8. Issue 4.

Holttum, S. (2013). Improving Social Inclusion for Young People Diagnosed with "First Episode Psychosis": Employment, Education and Online Support.Mental Health And Social Inclusion, 17, 112-117.

Kay, C., Fonda, N. \& Hayes, C. (1992). Growing an Innovative Workforce: A New Approach to Vocational Education and Training.Education and Training, Vol 34. Issue 5.

Lee, J, Kao.M and Yang. S (2012). Service Innovation and Smart Analytics for Industry and Big Data Environment. Procedia Cirp 16: 3-8

Liu, G. \& Clayton, J. (2016). Developing Instruments to Measure Perceptions of Technical Vocational Education and Training (TVET) Model Programme Provision.There and Back: Charting Flexible Pathways in Open, Mobile and Distance Education, 87.Vol 4, Issue5. 
Macours, K., Premand, P. \& Vakis, R. (2013). Demand Versus Returns? Pro-Poor Targeting of Business Grants and Vocational Skills Training.

Matlay, H. (2008). Vocational Education, Training And Learning In Smaller Businesses.Educational Training, Vol 50 Issue 5.

Metz, K. (2010). Benefits of Online Courses in Career and Technical Education Techniques: Connecting Education and Careers (J1), 85, 20-23

Pereira, E., Kyriazopoulou, M. \& Weber, H. (2016). Inclusive Vocational Education And Training (Vet)-Policy And Practice. Implementing Inclusive Education: Issues In Bridging The Policy-Practice Gap. Emerald Group Publishing Limited.

Richardson, K. \& Van G. J. (2002). The Effect of Vocational Employment Training on the Individual Transition Rate From Unemployment To Work. The Employment. Vol 4, Issue 3.

Rogers. A, (2012), Innovation in Lifelong Learning: Participation and Vocational Learning. International Review of Education Vol 58,

Schmidtke. C and Chen. P (2012)Philosophy of Vocational Education in China: A Historical Overview.Journal of Philosophy of Education, Vol. 46, No. 3, 2012.

SeyihogluAyşegüland Kaptan SeherYarar(2011), Elementary Students' Opinions of Learning Objects: A Social Studies Course Case. Journal of Educational Science and Research, International e-journal, Vol 1, No 2, December 2011.

Smits, W. (2008). The Private Benefits from Vocational Training: A New Framework. Cedefop, Office for Official Publications of the European Communities, Luxembourg.

Tripney J. S and Hombrados. G (2013) Technical and Vocational Education and Training (TVET) for Young People in Low and Middle-income Countries: A Systematic Review and Meta-analysis. Empirical Research in Vocational Education and Training, 2013, 5:3.

Van Gelderen, M., Van De Sluis, L. \& Jansen, P. (2005). Learning Opportunities and Learning Behaviour of Small Business Starters: Relations with Goal Achievement, Skill Development and Satisfaction. Small Business Economics, 25, 97-108. 